\title{
RENĀTE BERGA
}

Latvijas Nacionālā bibliotēka, Latvija

\section{HERMANIS SAMSONS UN RĪGAS AKADĒMISKĀS ĢIMNĀZIJAS DISERTĀCIJAS}

\section{İss kopsavilkums}

Hermanis Samsons (Hermann Samson, 1579-1643) dzimis Rīgā, studējis Rostokā un Vitenbergā, vēlāk pildījis mācītāja pienākumus Rīgas Domā un Pētera baznīcā, 1622. gadā kḷuvis par Vidzemes superintendentu. 1631. gadā H. Samsons ar Zviedrijas valdības atbalstu dibināja Rīgas akadēmisko ǵimnāziju, bija tās pirmais inspektors un turpmāko mūžu strādāja ǵimnāzijā arī par profesoru.

Jau Rīgas Domskolas un vēlāk arī akadēmiskās ǵimnāzijas mācību procesā tika lietota no Rietumu universitātēm aizgūtā disertāciju metode. H. Samsons kā daudzu disertāciju autors un vadītājs ieviesa arī humānisma idejas un ideālus savu studentu sacerējumos. Viṇa darbs Logicae systema (Rīga, 1620) - būtisks Rīgas izglītības vēstures mantojums - sniedza studentiem teorētiskas zināšanas un piemērus no teologiskiem un filozofiskiem tekstiem par disertāciju sacerēšanu.

Līdz mūsu dienām ir saglabājušies vismaz 83 Rīgas akadēmiskās ǵimnāzijas disertāciju izdevumi (H. Samsons ir vadījis vai bijis autors vismaz 27 no tām). Šie teksti līdz šim nav pētīti kā kopums. Disertāciju kā jaunlatīṇu literatūras analīze l̦autu veidot jaunus secinājumus par 17. gadsimta Rīgu Rietumeiropas izglītības vēstures kontekstā.

Atslēgvārdi: Rīgas akadēmiskā ǵimnāzija, Hermanis Samsons, akadēmiskās disertācijas, jaunlatīṇu literatūra.

\section{Ievads}

Kopš 20. gs. 90. gadiem Eiropā ir novērojama jaunlatīṇu literatūras pētnieku interese par 17.-18. gs. akadēmiskajām disertācijām (angl. early modern dissertations), kas tapušas kā sena mācību iestāžu tradīcija pasniedzēja un studenta kopdarbs. Somijā, Zviedrijā, Igaunijā, Lietuvā un citās valstīs klasiskie filologi un seniespiedumu bibliogrāfi ir jau daudz paveikuši disertāciju un citu akadēmisko tekstu - runu, sacerējumu un tiem pievienotās okazionālās dzejas - tulkošanas un zinātniskās 
izpētes jomā. Arī Latvijai ir savs literārais mantojums, kas līdz šim nav analizēts kā kopums.

Šî raksta mērḳis ir sniegt īsu ieskatu par Rīgas akadēmiskās ǵimnāzijas dibināšanas apstākḷiem, tās inspektoru, ievērojamo Livonijas garīdznieku H. Samsonu, izceḷot viṇa kā teologijas profesora mantojumu, kā arī aktualizēt nepieciešamību pēc sistemātiska akadēmisko disertāciju pētīšanas, tulkošanas un analizēšanas darba.

\section{Rīgas Domskola un akadēmiskas ǵimnāzijas tapšana}

Dibināta līdz ar Domkapitulu 1211. gadā, Rīgas Domskola viduslaikos bija gandrīz vienīgā un noteikti lielākā mācību iestāde un nozīmīgākā gan izglītības kvalitātes, gan skolēnu skaita ziṇā tagadējās Latvijas teritorijā. Gadsimtu gaitā tā attīstījās un uzplauka. 16. gs. beigās Rīgas rātes skolu kolēgija ierosināja izveidot ǵimnāzijas apmācību, kur mācības varētu turpināt Domskolu absolvējušie, lai tiem būtu vieglāk uzsākt studijas universitātēs. Diemžēl 30 gadus ilgais poḷu-zviedru karš aizkavēja šīs ieceres realizēšanu. Par spīti badam un karam, mācības Rīgā noritēja ierastajā kartībā un daži uzṇēmīgākie absolventi devās studēt uz Vācijas, Holandes un citu valstu universitātēm. Izcilākie no viṇiem saṇēma arī Rīgas rātes stipendijas. 1631. gada 18. aprīlī Zviedrijas karalis Gustavs II Ādolfs parakstīja lēmumu par Rīgas akadēmiskās ǵimnāzijas izveidošanu. Ģimnāzijā noritēja rosīgs un nopietns darbs, par ko liecināja arī biežie zinātniskie priekšnesumi un profesoru un studentu kopdarbu disertāciju - priekšlasījumi. Mācību iestāde darbojās līdz 1710. gadam, kad Rīga tika iekḷauta Krievijas impērijas sastāvā. Pēc Ziemeḷu kara Domskola tika pārveidota par klasisku ǵimnāziju un turpināja savu darbību (Staris 2011, 47).

\section{Rīgas akadēmiskās ǵimnāzijas disertācijas}

Disertāciju sacerēšanas tradīcija, kas aizgūta no Rietumeiropas universitātēm, tika izmantota jau Rīgas Domskolā un turpinājās arī Rīgas akadēmiskajā ǵimnāzijā. Nereti ḷoti grūti un dažreiz neiespējami ir noteikt īsto teksta autoru, jo tas varēja būt gan prezidents (praeses) profesors, kurš vadīja darbu, gan respondents (respondens) - audzēknis, kurš to aizstāvēja, gan arī kāda cita persona (Sjökvist 2012, 12). Iespiestie teksti tika izdalīti klausītājiem, lai iepazīstinātu viņus ar darba saturu, pirms audzēknis to nolasīja. Šo sacerējumu galvenā vērtība slēpjas to 
unikalitātē - pateicoties formai un saturiskajam piepildījumam, tie ir aplūkojami kā savdabīgi literāri sacerējumi ar kultūrvēsturisku nozīmi, jo akadēmiskās disertācijas ir viens no retajiem avotiem, kas raksturo izglītības saturu un kvalitāti Rīgas intelektuālo sabiedrību interesējošajās jomās. Šo tekstu, kas vērtējami arī kā literāri darbi, tematika ir daudzveidīga, jo ir pārstāvēta filozofija, vēsture, ētika, literatūra un citas jomas. Tajā pašā laikā var apgalvot, ka disertācijas ir savā ziṇā saistīti teksti, pateicoties humānisma idejām, kas tās caurstrāvo. Lìdz mūsu dienām lielākajās Latvijas seniespiedumu krātuvēs - Latvijas Nacionālajā bibliotēkā un Latvijas Universitātes Akadēmiskajā bibliotēkā - ir saglabājušies vismaz 83 Rịgas akadēmiskās ğimnāzijas disertāciju izdevumi.

H. Samsons bija aktīvākais Rīgas akadēmiskās ǵimnāzijas dibināšanas veicinātājs, ar Zviedrijas valdības atbalstu viņš panāca to, ka 1631. gada 18. aprīlī mācību iestāde tika atvērta. Vadot teoloǵijas katedru un strādājot par profesoru, viņš piedalījās gan kā vadītājs, gan kā autors vairāku disertāciju sacerēšanā.

\section{Hermaṇa Samsona biogrāfija un intelektuālais mantojums}

Pirms H. Samsona biogrāfijas aplūkošanas ir vērts precizēt ziṇas par tās būtiskākajiem avotiem. H. Samsona audzēknis Johans Brēvers (Johann Brever, 1616-1700), kurš vinuu ir saucis par savu garīgo tēvu un draugu (Brever 1655, 19), ir sacerējis vairākas runas H. Samsona bērēm, kā arī sastādījis viṇa piemiņai veltītu rakstu krājumu Memoria Samsoniana. Divas tajā ietilpstošās runas viņš ir sacerējis pats, vienu Petrs Hollers (Petrus Holler, ?-?) - Oratio de vita Beati Samsoni, pēdējo Hieronīms Depkins (Hieronymus Depkin, ?-?) - Comparatio Samsonis Biblici cum Livono. Pēc H. Samsona nāves šīs runas ir nolasītas ǵimnāzijas zālē, bet 1655. gadā Frankfurtē iespiestas kā pielikums J. Brēvera sastādītajam akadēmisko runu krājumam (Brever, Johann. Orationum, in Rigensi Athenaeo habitarum, pars prima [-altera]. Francofurti ad Moenum : Sumptibus Petri Hauboldii, anno M. DC. LV. [1655]). Otrs svarīgs avots, kas veltīts H. Samsona dzīvesgājumam un publiskajai darbībai, ir baltvācu vēsturnieka Kristiāna Augusta Berkholca (Christian August Berkholz, 1805-1889) sarakstītā H. Samsona biogrāfija, publicēta 1856. gadā (Berkholz, Christian August. M. Hermann Samson, Rigascher Oberpastor, Superintendent von Livland etc. : eine kirchenhistorische Skizze aus der ersten Hälfte des siebzehnten Jahrhunderts. Riga : Edmund Götschel, 1856). 
H. Samsons ir dzimis no Holandes ieceḷojušas militārpersonas ǵimenē 1579. gadā Rīgā. Mācījies Domskolā, saṇēmis Rīgas rātes stipendiju studijām Vācijas luteriskajās universitātēs, 1599. gada augustā imatrikulēts Rostokas un 1600. gada maijā - Vitenbergas universitātē. Pirmajā viņš studējis grieḳu un latīṇu valodu, otrajā - teologiju. Rostokā un dažus Vitenbergā tapušos studiju darbus H. Samsons velta savam mecenātam - Rīgas birǵermeistaram Nikolajam Ekem (Nicolaus von Ecke, 1541-1623) un citiem atbalstītājiem - garīdzniekiem un rātes darbiniekiem. 1600. gadā Rostokā prezentējis Runu par apmelojuma dabu un pazìmèm (Samson, Hermann. Oratio de natura et proprietatibus calumniae. Rostock : Christoph Reusner aus Neustadt, 1600). Vācijas bibliotēku krājumos saglabājušies vismaz seši H. Samsona studiju darbi. Viṇa teoloǵijas profesors - plaši pazīstams luterāṇu teologs, nelokāms antikalvīnists Salomons Gesners (Salomon Gesner; Gessner, 1559-1605) kādas disertācijas, kas vērsta pret Romas pāvesta varu, priekšvārdā izsaka pateicību Rīgas rātes amatpersonām par šì audzēkṇa atsūtīšanu uz Vitenbergu un saredz vin̄ā ne tikai perspektīou studentu, bet arī ieguvumu nākotne visai baznīcai, turklāt sakot, ka H. Samsons atdarina Bībeles Samsonu, šūpojot pāvesta troni, kas turas uz melīgiem balstiem (Gesner; Samson [1604], [4]). Jau H. Samsona dzīves laikā šos Gesnera vārdus varēja saukt par pravietiskiem. Vitenbergā H. Samsons piedalījās daudzās ikgadējās disputācijās kā respondents, bet nereti arī kā autors. 25 gadus vecumā jaunais teoloǵijas maǵistrs H. Samsons pieredzēja īpašu pagodinājumu tika novērtēts viṇa oratora talants, uzticot teikt runu par godu Mārtiṇa Lutera 60. miršanas dienai (Berkholz 1856, 33).

Vitenbergas studiju laikam bija būtiska loma ne tikai H. Samsona izglītībā, bet arī nākotnes sakaru un attiecību veidošanā, jo tolaik viņš iepazinās ar vairākiem topošajiem Zviedrijas garīdzniekiem, kā arī valsts pārvaldes darbiniekiem, piemēram, vēlāko kancleru Akselu Uksenšērnu (Axel Oxenstierna, 1583-1654). Šis fakts ietekmēja visu vēlāko H. Samsona darbību zviedru pārvaldītajā Rīgā (jāuzsver, ka ar aktīvu H. Samsona līdzdalību tika realizēti agrākie Rīgas rātes centieni paplašināt Domskolas mācību sistēmu līdz gimnāzijai). 1608. gadā rāte aicināja savu stipendiātu atpakaḷ uz Rīgu. Vitenbergā viṇam jau bija piedāvāts mācītāja amats, taču viņš vēlējās atgriezties. Atstājis telpu, kur neapšaubāmi dominējusi luteriskā teoloǵija, Rīgā atkal bija jāsastopas ar pretreformācijas un jezuītu ietekmi. Turpmākajos gados tapa plašs sacerējumu klāsts - sprediḳi, rokasgrāmatas studentiem, svinīgas 
runas, vēstules - latīnu un vācu valodā; tie iespiesti lielākoties Rīgā, bet arī Lībekā, Hamburgā, Gīsenē, pa kādam - Tartu un Stokholmā; organizēts jaunas Rīgas dziesmu grāmatas izdevums. H. Samsona - izcila sprediḳotāja, kaislīga jezuītu un pāvesta varas pretinieka, raganu prāvu teorētiskā pamatotāja un Vidzemes superintendenta - darbība ir padziḷināti pētīta un apspriesta. Šì raksta mērḳis ir ielūkoties viṇa kā teoloǵijas profesora mantojumā.

Atgriezies no Vitenbergas, H. Samsons stājās Domskolas inspektora amatā, šim notikumam par godu nolasot runu De origine et utilitatibus scholarum (Samson, Hermann. Oratio de origine et utilitatibus scholarum. Rigae Livonum : Typis Nicolai Mollini, M.DC.VIII [1608]). Viņš teic, ka Vācijas universitātes ir radušās pēc Aleksandrijas patriarhu laika kristiešu skolu parauga - skolas var visvairāk palīdzēt baznīcām un valdībām, ja vien evangéēliju doktrīnas tur tiek pareizi mācītas, nesajaucot teoloǵijas un filozofijas principus; tāpat arī filozofija nedrīkstot pār teologiju dominēt, bet drīzāk pakalpot un palīdzēt (Samson [1608], [14]).

1611. gadā iespiesta H. Samsona sastādītā ticības pantu rokasgrāmata Domskolas audzēkṇiem Enchiridion articulorum fidei (Samson, Hermann. Enchiridion articulorum fidei. Rostochii : Typis Christophori Reusneri, ANNO 1611), kur plašs teoloǵisks saturs izkārtots jautājumu un atbilžu veidā. Otrs H. Samsona kā inspektora izdevums Logicae systema ir iespiests 1620. gadā (Samson, Hermann. Logicae systema. Rigae Livonum : Excudebat Nicolaus Mollinus, Anno M.DC.XX [1620]). Tāpat kā rokasgrāmatā, arī šeit materiāls ir izkārtots tematiski iedalītu jautājumu un atbilžu veidā, sniegti piemēri, kas studentiem palīdz sagatavoties disputiem, strādāt ar argumentiem un silogismiem (Berkholz 1856, 51-52). Logicae systema ievadā H. Samsons citē Augustīnu: Tā arī Augustīns darba "Par kristīgo mācību" 2. grāmatas 31. nodal̄ā saka: disputāciju disciplīna ir visvērtīgākā, lai iedziļinātos un atšķetinātu visu veidu jautājumus, kas svētajos rakstos atrodami. (Samson [1620], [5])

Latvijas Universitātes Akadēmiskās bibliotēkas Rokrakstu un reto grāmatu nodaḷā pētniekiem pieejami divi šì iespieddarba eksemplāri, no kuriem viens piederējis autoram - ar katru otro lapu iesietu tukšu, tās H. Samsons ir izmantojis piezīmēm.

Kā minēts, H. Samsonam bija ḷoti liela loma akadēmiskās ğimnāzijas dibināšanā, viņš bija arī tās pirmais inspektors un līdz mūža beigām strādāja par teoloǵijas profesoru, tādējādi viṇa pienākumos ietilpa arī 
darbs kopā ar studentiem - vadīt vai izstrādāt disertācijas. Viṇa vadībā tapis liels to skaits, un līdz mūsu dienām saglabājušās vismaz 27.

K. A. Berkholcs citē H. Samsona runu, ko viņš teicis 1631. gada 5. aprīlī īsi pirms gímnāzijas atvēršanas un kas, visticamāk, līdz mūsu dienām nav saglabājusies. Beigas ir šādas: Un tā pēc Dieva prāta no augsti godātās rātes teologíijas profesora amats man ir piedāvāts un uzticēts, es likšu priekšà vispārpien,emtas teoloǵiskas patiesības pēc tēzes un antitēzes metodes un 20. aprīḷa devītajā stundā sākšu lekcijas. Turklāt pēc dažiem vingrinājumos pavadītiem mēnešiem es savus klausìtājus uz ìsu brīdi nodarbināšu ar disputāciju ieročiem, lìdz kamēr izšķirošajā brìdī vin̨i varēs iziet pie publikas. Tomēr viņiem visiem inaugurācijas runu pēc senas paražas es pateikšu 14. aprìlì. Tā klausīties šo runu es visus izglītotos mīḷi un pakalpīgi ielüdzu. Mağistrs Hermanis Samsons, mācītājs, superintendents un profesors. (Berkholz 1856, 95-96)

Samsons uzskatìja, ka ir bezjēdzīgi iesaistīties debatēs, ja nav pilnveidotas filozofijas un filologiijas prasmes. Studiju laikā viṇš slīpēja latīṇu un sengrieḳu valodas zināšanas, tulkojot tekstu fragmentus no vienas valodas otrā. Lai to labi paveiktu, viņš pastāvīgi krāja noderīgas metaforas un asināja savu izteiksmes stilu, un papildināja vārdu krājumu, prasmīgi atdarinot labākos autorus. Saskaṇā ar J. Brēveru H. Samsons tādējādi kḷuva Magnus in Graecitate, Magnus in Latinitate. Brēvers teic, ka H. Samsons apzināti kopis un aktīvi uzlabojis savu latīnu valodas stilu (Witte 1674-1675, 513). 2006. gadā Lundā publicētā pētījumā, kas apskata A. Uksenšērnam adresētās H. Samsona vēstules, norādīts, ka H. Samsons ir īpaši daudz izmantojis Erasma darbu Adagia jeb Parunas un ietekmējies no tā, tādējādi tiek arī pieņemts, ka šì saikne ar Erasmu norāda uz vienu no $\mathrm{H}$. Samsona valodas stila un izsmalcinātības avotiem (Dobreff 2006, 34).

\section{Hermanis Samsons - praeses et auctor}

Gandrīz pusei disertāciju, ko H. Samsons vadījis, viņš bijis arī teksta autors, par to liecina ziṇas titullapā - praeside et auctore. Šo sacerējumu saturs aptver ārkārtīgi plašu teoloǵijas interešu spektru, tiek diskutēts gan par dogmatikas, gan leksēmas Dievs morfologiijas, religiiskās morāles un ètikas, morālfilozofijas, apologēetikas, reliğisko rituālu, ǵimenes tiesību un, protams, luterānisma aspektiem.

H. Samsons dedzīgi aizstāvēja uzskatu, ka kristietība Rīgā un Livonijā ienākusi, pateicoties Kārlim Lielajam, nevis Romas pāvestam 
(Berkholz 1856, 67). L,oti būtiska vieta ir arī disputācijām, kuru saturs vērsts pret kalvinismu, katolicismu un Romas pāvesta varu. Tās ir iemesls, kādēḷ var teikt, ka polemika ar jezuītiem turpinājās visu H. Samsona mūžu. Gandrīz katra disertācija satur pazīstamāko jezuītu, it īpaši Svētā Roberta Bellarmīna, kā arī Trentas koncila, kritiku. 1641. gadā Viḷnā publicēts kāda, domājams, Viḷnas jezuītu ordeṇa brāḷa Hermēta Kirīna - sacerējums Rīgas antikrists jeb Hermanis Samsons. Nelielais duodecimo formāta iespieddarbs sākas ar vārdiem: Nesen manās rokās nonāca disputācijas par dižo antikristu jeb Romas pāvestu, kuru prezidents un autors ir Rīgas baznīcas amatpersona Hermanis Samsons. Tajās nav nekā cita kā tikai liekulība, apmelojumi un apvainojumi. (Cyrinus 1641, [3]) Nav ziṇu par to, vai un kāda ir bijusi Samsona atbilde šim oponentam, bet K. A. Berkholcs norāda, ka šis sacerējums pārspēj pats sevi rupjībā (Berkholz 1856, 171).

Jau H. Samsona disertācijās, kas tapušas viṇa studiju laikā Vitenbergā, var novērot to, ka viņš izmanto savas izcilās klasisko valodu zināšanas un vēršas ad fontes, kas ir tipiska humānisma metode, lai veidotu savu viedokli un nepopularizētu iespējamas priekšgājēju kḷūdas. Arī vēlāk, vadot studentu darbus, l,oti daudz uzmanības tiek veltīts tēmas svarīgāko terminu filoloǵiskajam aspektam. Piemēram, disertācijā Par saderināšanos, laulību un radniecīgiem pretrunīgiem jautājumiem (Samson, Hermann, Witte, Henning. Disputatio publica de sponsalibus, coniugio et cognatis controversis quaestionibus. Rigae Livonum : Typis Gerhardi Schröder, [1640]) skrupulozi apskatīti vairāku valodu - latīṇu, sengrieḳu un senebreju - termini, kas saistīti ar šo tēmu. Ir iespējams atrast saikni starp H. Samsona Vitenbergas studiju laika darbiem un Rīgā vadītajām disertācijām, piemēram, jau minētajā 1604. gada darbā, kas izstrādāts kopā ar profesoru S. Gesneru, detalizēti apskatīta Svētā Pētera vārda izcelsme un nozīme, šì pati tēma iztirzāta arī disertācijā, kas nolasīta 1631. gadā garīdznieku sinodē, un kādā 1637. gada disertācijā par Romas pāvesta primātu un monarhiju.

Būtiska humānisma kategorija - brīvā griba - ir aplūkota vairākās disertācijās, turklāt pat viena disertācija, kuras respondents ir jau minētais H. Samsona audzēknis J. Brēvers, tai ir veltīta pilnībā (Samson, Hermann, Brever, Johann. Disputatio publica de Libero Arbitrio. Rigae Livonum : Typis Schröderianis, Anno 1635). Autori sacerējumu ir veidojuši plašu un daudzpusīgu, gan iekḷaujot stoiḳu, Augustīna, Lutera un katolicisma nostādnes, gan apskatot brīvās gribas formas un veidus. 
13 gadu laikā, ko H. Samsons pavadījis teologijas profesora amatā, viṇa vadīto disertāciju tēmas ir atkārtojušās vien pāris reižu, lielākoties tās tikai papildinājušas cita citu. Līdzīgi Erasmam viņš bijis eklektisks latīnists, kurš krājis daudzu autoru frāzes un izteikumus, taču viņš arī apzināti kopis un centies padarìt izsmalcinātu savu latīṇu un grieķu valodas izteiksmi (Dobreff 2006, 34).

Izmantojot literatūras teorijā pieejamo kontekstuālo metodi, būtu padziḷināti jāpēta H. Samsona studiju darbi un vēlāk gimnāzijā vadītās disertācijas, tas atspoguḷotu to, kā luterānisma idejas un nostādnes tika izmantotas Rīgā.

Disertāciju publikācijas ir nenovērtējams uzziṇu avots pētījumiem arī par citiem 17. gs. Rīgas inteliǵences pārstāvjiem - gan ǵimnāzijas profesoriem, kuri sekmēja humānisma ideju izplatību Latvijas teritorijā, gan absolventiem, kuri vēlāk kḷuva par Rīgas rātskungiem, mācītājiem, zinātniekiem.

\section{LITERATŪRA}

1. Berkholz, Christian August. M. Hermann Samson, Rigascher Oberpastor, Superintendent von Livland etc. : eine kirchenhistorische Skizze aus der ersten Hälfte des siebzehnten Jahrhunderts. Riga : Edmund Götschel, 1856.

2. Brever, Johann. Memoria Samsoniana. Celebrata Anno M. DC. XLIV. Brever, Johann. Orationum, in Rigensi Athenaeo habitarum, pars prima [-altera]. Francofurti ad Moenum : Sumptibus Petri Hauboldii, anno M. DC. LV. [1655], [1]-98.

3. Cyrinus, Hermetes. Antichristus Rigensis sive Hermannus Samsonius. Typis Vilnensievs : s.n., Anno 1641.

4. Dobreff, James. Hermannus Samsonius to Axel Oxenstierna : Latin correspondence from 1621 to 1630 with linguistic and historical commentaries. Lund : Centre for Languages and Literature Lund University, 2006.

5. Gesner, Salomon, Samson, Hermann. Contra Antichristianum Primatum Romani Pontificis. Witebergae : Typis VVolffgangi Meisneri, Anno [1604].

6. Samson, Hermann. Logicae systema. Rigae Livonum : Excudebat Nicolaus Mollinus, Anno M. DC. XX [1620].

7. Samson, Hermann. Oratio de origine et utilitatibus scholarum. Rigae Livonum : Typis Nicolai Mollini, M. DC. VIII [1608].

8. Sjökvist, Peter. Music Theory of Harald Vallerius: Three Dissertations from $17^{\text {th }}$ Century Sweden. Uppsala : Acta Universitatis Upsaliensis, 2012.

9. Staris, Alfrēds. Rīgas Domskolai 800 gadu jubileja. Rīgas Domskola un izglītības pirmsākumi Baltijā: starptautiskas konferences zinātnisko rakstu krājums. Sast. Aīda Krūze, Iveta Ķestere, Alīda Zigmunde. Rīga : RaKa, 2011, 34-59.

10. Witte, Henning. Memoriae theologorum nostri saeculi clarissimorum renovatae decas prima (- sexta). Königsberg, Frankfurt (Main) : Hallervord, 1674-1675. 


\section{HERMANN SAMSON AND DISSERTATIONS OF RIGA ACADEMIC GYMNASIUM}

\section{SUMMARY}

Hermann Samson (1579-1643) was born in Riga, studied at the universities of Rostock and Wittenberg, served as pastor at the Dome and Peter's Church; in 1622, he became the superintendent of Livland. The support of Swedish government permitted him to establish the Riga Academic Gymnasium, where he acted as its first inspector and the professor of theology for the rest of his life.

A method of dissertations was adopted from Western universities and included in Riga educational institutions' curriculum. H. Samson as the author and/or president of many dissertations introduced the ideas and ideals of humanism into his students' writings. Theoretical material on dissertations with examples from theology and philosophy "Logicae systema" (Riga, 1620) compiled by H. Samson form an important legacy of Riga's education history.

Approximately 130 printed dissertations of the Riga Academic gymansium are extant $(\mathrm{H}$. Samson was the author and/or president of at least 27 of them). These texts have not yet been studied as a corpus. The analysis of the dissertations as an example of Neo-Latin literature might bring new conclusions regarding the $17^{\text {th }}$ century Riga in the context of Western European history of education. 